\title{
Editor's Note - Received Date Error, Int. J. Environ. Res. Public Health 2009, 6, 2387-2396
}

\section{Gardenia You}

MDPI Beijing Office, Floor 4, Chelifen Village Committee Office Building, Liyuan Town, Tongzhou District, 101101 Beijing, China; E-Mail: gardenia.you @em.mdpi.org; Tel.: +86 10605288 33; Fax: +8610605247 74

Published: 3 November 2009

Editor's Note added on 3 November 2009: The received date was wrong in Int. J. Environ. Res. Public Health 2009, 6, 2387-2396. It should be 29 July 2009 instead of 29 July 2008.

\section{References}

1. Zhao, Y.; Malyon, R. Life Years at Risk: A Population Health Measure from a Prevention Perspective. Int. J. Environ. Res. Public Health 2009, 6, 2387-2396.

(C) 2009 by the authors; licensee Molecular Diversity Preservation International, Basel, Switzerland. This article is an open-access article distributed under the terms and conditions of the Creative Commons Attribution license (http://creativecommons.org/licenses/by/3.0/). 